\title{
THE MAKING OF THE FILM BRIDGE (2016): THE ALCHEMIC PROCESS OF TRANSFORMING SELF AND SOCIETY
}

\author{
Amit R. Biswas \\ Film maker, writer, and child neuropsychiatrist (India)
}

\begin{abstract}
The author and director of the film Bridge (2016), Amit R. Biswas, reflects on the process of film-making, using strategies that deal with self (and, therefore, social) transformation through art. In a sort of inner confession monologue, he delves not only into the more anecdotal part of the logistics and economic tour-de-force problems that producing a film involve; but also, and more interestingly, in the causes, nuances, and psychological details that are contained in the plot. Seen as a process of catharsis and posterior anagnorisis, the film unveils the subtle influences that underlie human contact, the transformation of the human psyche by means of compassionate attitudes, and the mutual redemption suffered by the seeming victim and his apparent saviour, in a sort of alchemic metempsychosis released by mutual understanding and empathy.
\end{abstract}

Keywords: Amit R. Biswas, Bridge (2016), Filmmaking Process, Alchemic Transformation.

\section{EL PROCESO DE CREACIÓN DE LA PELÍCULA BRIDGE (2016): \\ EL PROCESO ALQUÍMICO DE TRANSFORMARSE \\ INDIVIDUAL Y SOCIALMENTE}

\section{RESUMEN}

El autor y director de la película Bridge (2016), Amit R. Biswas, reflexiona sobre el proceso de creación y producción cinematográficas, utilizando para ello estrategias que tienen que ver con la transformación del yo (y, por ende, de la sociedad) a través del arte. En una suerte de monólogo-confesión interior, el director profundiza no solo sobre esa parte más anecdótica de la logística y de los enormes problemas económicos que se suscitan cuando se produce un largometraje; lo hace también, lo que es más interesante, sobre las causas, matices y detalles psicológicos que están contenidos en la trama. Visto el film como un proceso de catarsis y posterior anagnórisis, se desvelan en él las sutiles influencias que subyacen en el contacto humano, la transformación de la psique por medio de unas actitudes compasivas, y la redención mutua que sufren la aparente víctima y el que parece su salvador, en una metempsícosis alquímica catalizada por la comprensión y la empatía mutuas.

Palabras Clave: Amit R. Biswas, Bridge (2016), producción cinematográfica, transformación alquímica. 
In today's world, films and visual media dominate our cultural stratosphere as the most available and accessible form of creative expression. The journey of films began with the first public demonstration by the Lumiere' brothers with their new device, the Cinematographe, in the basement of Grand Cafe in Paris. Since then, suspended between realism and illusion, cinema has transformed our lives in unprecedented ways. Film is both an art and a science, perhaps a bridge between our left and right hemispheres of the brain but also it creates connections between our internal and external worlds, psychologically, emotionally socially, culturally, and spiritually.

The journey of making and subsequently presenting our film Bridge (2016) to the audience worldwide was a transforming experience for me and the Team Bridge, not only as film makers but also as human beings. The central message of the film is the importance of unconditional human bonding and kindness in human lives. In this process, it was wonderful to see that our multi-cultural team of individuals also related deeply, co-creating something beautiful and purposeful. The making Bridge was collective and throughout the process, we worked together with a sense of higher purpose, to make something greater than ourselves.

\section{STORY OF THE FILM AND CHARACTER TRANSFORMATION}

Bridge is a life affirming and heartwarming story of the chance meeting of two suicidal strangers on a bridge over the Ganges. They are both experiencing immense emotional distress. At dawn, Tanima, a young woman and Santanu, an octogenarian, are seen on a bridge, evidently both intending to commit suicide. Noticing Tanima about to jump off the bridge and driven by the sheer impulse of saving her, Santanu momentarily forgoes his own suicidal thoughts and runs to stop her from jumping off the bridge. He brings her home. Tanima continues to be in great distress and remains suicidal; refusing interactions, even food and resisting every help offered. Santanu does not give up. As he tries to figure out a way forward, he slowly gets to understand Tanima's trauma and painful past. Santanu does not only show great compassion and determination and the sequence of events allow him to connect with his own unresolved grief. Although, their meeting initially brings great challenges but through gradual building of a bridge of deep trust and bonding, eventually both heals, regaining a sense of meaning and belonging to life.

\section{WHY THIS FILM? BACKGROUND STORY OF THE PURPOSE}

My own creative journey evolved through a gamut of artistic forms; being a performer and choreographer of Indian Classical dance (Kathak) to a director of Dance theatres; from being a poet and playwright to a screenplay writer; from making short films, documentary and awareness films to evolve towards a feature film maker. After traversing and experiencing this long journey through various 
genre of creative expression, I needed to find a single but wider canvas where I can seamlessly blend the colors of science and arts to involve and inspire people across cultures. My vision was to make international films deeply rooted in Indian culture with a universal theme in appeal.

Apart from being a film maker I am also a senior Consultant Child \& Adolescent Neuropsychiatrist and an educator based in UK. I am a firm believer that 'recovery' is not just about reducing 'symptoms'. Instead, 'healing' happens through engaging various dimensions, beyond the physical- namely emotional, cognitive, behavioural, social, and spiritual. When clinicians can see the individuals in a holistic way and applies a 'person centred approach' in their work, the process of recovery starts. Clinicians are highly skilled and experienced individuals, but it is also important to approach patients with kindness, an "Intelligent kindness" (Ballatt and Campling 1) where they can build trust through empathic connection. This is otherwise called 'therapeutic alliance', one of the most important factors in the recovery process.

In the past, in my creative work, I was keen to raise bigger questions of life, through musicals or through plays. The vision of Bridge was also to raise questions: what heals and transforms us? How we create hope/optimism and how important is kindness and compassion in our lives? While developing the idea of my film, I attempted to bring together three aspects: the psychological insights I gathered from working with young people with severe mental illness, my worldview beyond materialism and my creative vision to make a film that will create a greater and lasting impact on society.

\section{INSPIRATIONS}

My inspiration from Bridge came from my direct experiences of clinical work with young people and families to whom I am highly indebted to. Psychiatrist and holocaust survivor Viktor Frankl's life changing book Man's Search for Meaning, deeply moved me and inspired my directorial vision of Bridge. Like Stoic philosophers, Frankl's prophetic words made a deep impression because they gathered the inner strength of individuals to change their own life as well as life in general.

I was initially influenced by legendary film makers such as Satyajit Ray, Akiro Kurosawa, Andrei Tarkovski but after emigrating to UK, I was exposed to a wide range of European and American filmmakers and directors such as Krzysztof Kieslowski, Louis Bunuel, Michael Haneke, Steven Spielberg, Woody Allen, Robert Bresson, Abbas Kirostami, Jean Luc Goddard, Pedro Almodover and many others whose footprints are evident in my growth as a visual storyteller.

Soumitra Chatterjee (cast as Santanu in Bridge) who worked extensively with the lifetime Oscar winning film director Satyajit Ray has been a major influence in my life, a mentor, muse, friend, and creative collaborator. He directed and acted in plays I wrote that ran successfully in India for many years. He was a tremendous support and inspiration while I was conceiving and writing Bridge. 
Bridges have several metaphorical, symbolic and mythological meaning, of a passage or connections, a portal to cross. Majestic bridges like Howrah Bridge in Kolkata, India or Tower Bridge in London have always inspired me not just as a structure but something that tells many stories of human society and history.

\section{THE JOURNEY OF A HERO}

I am highly influenced by the ideas of philosopher Joseph Campbell in Hero with Thousand faces (1973) and later by the Hollywood screenwriter Christopher Vogler (gathered in The Writer's Journey). Both point out that the ideas embedded in mythology can be applied to understand almost any human problem. Many stories also contain a mythic dimension which can strongly affect and catalyse transformational process.

According to Carl G. Jung's theory, we inherit as a part of our humanity (1927). Mythical stories can be taken as a projection of the collective unconscious as a collective 'dream.' An individual is a part of the whole species in the long evolutionary journey and the pattern of myths are used in many fairy tales, novels, plays and more recently, in screenplays. The stages of the journey of a Hero can be traced to all kind of stories such as Dorothy's voyage in Wizard of $O z$ ). The protagonist goes through various phases; of hesitation and fear of taking up a challenge, meeting mentors, facing conflicts and crises, confronting fear finally leading to release of old ideas and undergoing inner change through gaining new perspectives.

I felt the urge to create a film which with have that mythic dimension, as films are an important part of our evolving mythology. While writing Bridge, I was very mindful of this journey and the transformative power of mythology, symbols, and metaphors. These have been used for a long time both in psychotherapy and films. These films in turn can help and support an individual to strive towards personal growth and transformation by connecting them on a mythological level. The viewers alongside the filmmakers can tap into their greater wisdom, reassessing their inner capacity and aligning with their deepest and wisest self. In literature, it is reported that as viewers gain a new perspective, a possibility of discarding old ways of, as Simon states (2002), living arises and new maps of behaviour are forged.

\section{THE PROCESS OF ALCHEMY}

Marsha Sinetar' Reel Power-Spiritual Growth through Film recognized movies as tools for personal transformation. The movement started to revive again in 2019 with the featured documentary Calypsonians by director Anghelo Taylor. Perhaps like other debutant director/ producers, we endured seven long and frustrating years to secure money for the film unsuccessfully from various companies and financiers. I knew that I needed to make this film desperately. Eventually, I decided to raise the money from my personal funds, pension policies, investments and so on. Preproduction of the film started in February 2014 and we eventually finished 
it at the end of the year on a shoe string budget. Most of the cast and crew worked on a fraction of their fees not only because they were inspired by the script but also because many of them believed that making this film was 'essential.'

We met Zoran Veljkovich, our cinematographer, an experienced and respected professional in the UK and a teacher at Raindance Film School at BAFTA way before the funds were raised for Bridge and I remember our mutual excitement and passion about making Bridge. I am still deeply indebted to him for believing and being inspired by my vision. It was not easy for Zoran to film in India. He did not know the language, most of the crew spoke scanty English. Also, as the summer months approached, it was not only him suffering in the heat, even his equipments were getting exhausted. However, excellent body language, locally produced meals, caring caterers and tea boys kept him nourished and for the first time shooting in India he maintained a bug-free tummy for five weeks.

We were fortunate to have Paramita Banerjee as the producer and Arghyakamal Mitra, an award winning and highly experienced editor, in our team. Abhijit (Tenny) Roy our sound engineer walked the alleyways of Bally day and night, coaxed locals for organic sounds, begged boatmen to take him to the middle of the river to record sounds of waves. Our supremely talented young music director Dishari, moved in with me in our home for several weeks, went without sleep for days, shortlisted instruments from hundreds to create the apt soundtrack of Bridge. Renowned still photographer and artist Suvomoy Mitra was inspired by the script and he offered his services for free and took incredible production stills which are invaluable. Three film school students from three different Universities came along to shoot 'behind the scenes' footage and became an integral part of our team. Similarly, highly and globally regarded colourist Dado (Valentic), well known art director Goutam Basu, famous singer Upal Sengupta and many others joined us along in our journey and co-created the film.

On the first day of our shoot, I led a meeting, sitting in a circle with a candle in the centre. Everyone in the team introduced themselves and answered the question 'what do you love about cinema and why are you in the business of film making?' Seventy-five people talked openly about themselves, their passions, their beliefs and their lives and what they loved about movie-making. We felt a growing sense of a community; individuals gathered with a single purpose, to make a great film that heals and transforms.

As in every low budget filmmaking, the most difficult aspect was to manage the production and postproduction of the film within the limited budget. It was also a challenge to maintain the effective communication and coherent understanding between the international crew members with different outlook in practical approaches and practices and linguistic differences. It was all possible because we connected and cared for our film.

The film was mostly shot at a family home of our producer which was generously provided for free. The members of the household eventually became a part of the cast and the crew. The locals in the otherwise quiet town of Bally were extremely excited and participated in every way they could. The cooperation from them was invaluable. Local youngsters who had no idea about film making became an integral part of the crew. To our utmost surprise, the idol of Kali that was created 
for the film was transformed from a mere prop, a part of the set design to a sacred entity that the locals worshipped. Almost every aspect of making this film was 'fun' just because as a team, we were inspired to make it happen. But dealing with a huge number of extras and involving residents and local people of Bally, was albeit frantic but gave us great joy and satisfaction. Our youngest actress was only 18 months old and it was a delight to work with her and other children who gave 'perfect' hots every time. The sense of humor of the entire crew, the positive attitude and the feel-good factor within the team kept us going even in a stressful and challenging schedule coupled with hot and humid weather. Overall, we felt that it is not just the cast and crew but the community in Bally created the film and held it together with love, affection, curiosity and enthusiasm that sustained all of us.

Nature also helped us in many ways and we all felt blessed. To give an example, we did not have enough money to hire a rain machine for 3 days that was the requirement of the film. We used artificial rain on one day but to our utmost surprise, we were rewarded with a downpour and thunderstorms for the other two just when we needed them.

Before every shot, we practiced a Mindfulness based exercise or meditation that started with the ringing of a Tibetan bell. This was new to our cast and crew, to pause and be in stillness before 'Action"! However, they allowed themselves to go with the process and later talked about their experiences. Many felt that it was really helpful to be fully attentive and focused before the scenes were shot. The cast and crew continued talking and reflecting about their experiences even after the shooting was finished.

There were indeed differences in opinion and disagreements during the creation of Bridge but given our heartfelt connections, commitment towards our film, we were able to hold meaningful and constructive dialogues, throughout the process. We were always able to find common grounds, as all of us always kept the film at the center of our vision keeping at bay egos and opinions.

\section{USING BRIDGE TO TRANSFORM AND HEAL}

The use of movies for personal growth, transformation and healing comes from a long-standing connection between storytelling and self-reflection dating back to the beginnings of spoken language. Many cultures throughout the human history have recognized the transformative and healing effect of the act of telling and listening to stories. Potential impact of films on health can be traced back to Mellon's concept of Bibliotherapy (2003), which was used by ancient Greeks with the use of 'engaged reading' to gain insight into one's psyche. Greeks used drama in their visual and performing arts as a catharsis to deal with their emotions and trauma. Neimiec \& Wedding argued in 2008 that the appropriate movies speak to the non spoilt spot that is present in all of us, where people escape from their lives into themselves and come out feeling better, stronger and more willing to take healthy action.

For me, the purpose and challenge of making Bridge were twofold: on the one hand to create a meaningful film that will move the viewers and raise questions 
and awareness with a potential to transform the viewers. On the other, I wanted to make a film that is aesthetically pleasing, stylistically distinct and cinematically of high quality. The balance needed to be right so that the vision is not lost in the techniques of storytelling or aesthetics and the cinematic beauty is not marred by the film's underlying message or psychological implications. A film can create, as Haidt states, a cinematic elevation by witnessing acts of moral beauty (such as humanity, courage, justice), through the physical sensations (like warmth, openness) and motivation to move towards higher morals. During the cinematic elevation, Haidt comments that an individual feels a sensation of inspiration which help them subsequently to take action for their own greater good or for others or society.

I used various psychological (especially psychoanalytic and positive psychology) musical, linguistic, visual and other techniques in a way that would enhance the evolution of characters and the central message without losing the fluidity of storytelling. I was aware that, as Gardner claims, we have multiple intelligences and the synergistic effect of movies can impact hugely on a person's physiological, psychological, and other dimensions, creating the potential for healing and transformation. Being a great fan of positive psychology, I was also aware that positive psychological approaches are not only about fixing what is broken, disordered or deranged but also nurturing what, in the tradition of Seligman \& Csikszentmihalyi (2007) is best. Researchers also found that films can directly and indirectly influence the character strength and inner virtues and enable individuals and communities to thrive and flourish, to "self-actualise" (Maslow 1971, 1987). I wanted Bridge to be in this genre of film that inspires, heals, transforms and one that focuses on the human strength of character. Hope and optimism that is portrayed in our film exemplifies this view about bouncing back from our adversities. With great delight, we have seen every audience moved and experiencing a cinematic elevation after watching Bridge and sharing with us experiences of feelings of positivity and optimism.

Bridge travelled the world in many festivals and received twelve international film awards, but I have also presented my first feature film in various professional and educational settings (University of Salamanca, University of Michigan, University of Pittsburg...), public gatherings and mental health awareness platforms to create dialogues on various relevant issues. This included the centrality of kindness and trusting relationships in human life, compassion-focused healthcare and, at the same time, raising awareness on suicide and mental health issues and confronting stigma. Apart from being asked on the processes of film making and directorial questions, it has been hugely satisfying and enlightening to create dialogues on topics that goes beyond Bridge as a film and its storyline.

It was a privilege and an honor to work with a talented, committed and connected team and to present our film to the global audience. We feel optimistic about our human condition and continue to celebrate our interconnectedness creating a meaningful impact on our lives. 


\section{WORKS CITED}

Ballat, John \& Penelope Campling. Intelligent Kindness: Reforming the Culture of Healthcare. RCPsych Publications, 2011.

Campbell, Joseph. The Hero with Thousand Faces. Bollingen Series/Princeton University Press, 1973.

Campbell, Joseph. The Power of Myth. Doubleday, 1988.

Frankl, Viktor E. Man's Search for Meaning. Ebury Publishing, 1946.

Gardner, Howard. Multiple intelligences: The theory in Practice. Basic Books, 1993.

HaIdt, J. Elevation and the Positive Psychology of Morality. Flourishing: Positive Psychology and Life Well Lived. Eds. L.M Keyes \& J. Haidt. American Psychological Association, 2003. 275-289.

Jung, Carl G. Man and His Symbols. Penguin Books, 1964.

Maslow, A.H. The Further Reaches of Human Nature. Penguin, 1987.

Maslow, A.H. Motivation and Personality. New York: Harper Collins, 1971 [1954].

Mellon, Nancy. Storytelling and the Art of Imagination. Yellow Moon Press, 2003.

Neimiec, Ryan M \& Danny Wedding. Positive Psychology at the Movies: Using Films to Build Virtues and Character Strengths. Hogrefe, 2008.

Seligman, M.E.P. \& M. Csikszentminalyi. "Positive Psychology: An Introduction". American Psychologist 55/1, 2000: 5-14.

Simon, Stephen. The Force Is with You: Mystical Movie Messages that Inspire Our Lives. Hampton Roads, 2002.

Sinetar, Marsha. Reel Power \& Spiritual Growth through Film. Triumph Book, 1993.

Vogler, Christopher. The Writers Journey: Mythic Structure for Writers. Michael Wiese Productions, 1998. 